\title{
THE POTENCY OF BOVINE BONE GELATIN AS ANTIHYPERTENSIVE AGENT: A REVIEW
}

\author{
Irma Khikmawati ${ }^{1)}$, Savira Margi Rahayu ${ }^{1)}$, Annisa Nur Amieni ${ }^{1)}$, Muhammad Cahyadi ${ }^{1,2)}$ \\ 1) Department of Animal Science, Faculty of Agriculture, Sebelas Maret University, Jl. Ir. Sutami 36A \\ Kentingan, Surakarta, 57126, Indonesia \\ 2) Halal Research Center and Services, Institute of Research and Community Service, Sebelas Maret University, \\ Jl. Ir. Sutami 36A Kentingan, Surakarta, 57126, Indonesia \\ *Corresponding email: mcahyadi@staff.uns.ac.id
}

Submitted 18 July 2021; Accepted 1 September 2021

\begin{abstract}
This review was purposed to understand the effectiveness of bovine bone gelatin as an antihypertensive agent. This review concerning the effectiveness of bovine bone gelatin as an antihypertensive agent. Hypertension, also called as a silent disease, has become the main cause of coronary heart disease and stroke that contributes to the malfunction of human organs. Changes of lifestyle alongside with science enhancement, provides new inventions regarding methods of hypertension therapy by minimizing the use of synthetic drugs. Collagen tissue of bovine bone gelatin is known to contain angiotensin converting enzyme (ACE) inhibitor, an active peptide that plays a role in lowering blood pressure supporting with the large amount of Gly (27\%), Pro (17.6\%), and Hyp (14.4\%) and repeating pattern of Gly-X-Y. A study was carried out in vivo using injected spontaneously hypertensive rats (SHR) with $30 \mathrm{mg} / \mathrm{kg}$ and was able to reduce blood pressure by $15 \mathrm{mmHg}$. Antihypertensive test with SHR tail-cuff at 30 $\mathrm{mg} / \mathrm{kg}$ bovine gelatin hydrolysate RGL-(Hyp)-GL and RGM-(Hyp)-GF were $31.3 \mathrm{mmHg}$ and $38.6 \mathrm{mmHg}$ respectively. A study conducted using bovine and porcine gelatin with $30-50 \mathrm{kDa}$ (permeate P1) and 1-2 kDa (permeate P3) was able to reduce blood pressure by $22 \mathrm{mmHg}$ and $21.33 \mathrm{mmHg}$. In addition, it is still possible conducting research to find out other peptides of bovine bone gelatin that can be used as a future alternative antihypertensive agent.
\end{abstract}

Key words: Antihypertensive activity; bioactive peptide; bovine bone gelatin; hypertension 


\section{INTRODUCTION}

Hypertension referred to as a silent disease is the main factor causing heart disease and stroke. In an uncontrolled condition, this silent disease will cause damage to other organs such as the brain, kidneys, eyes, and movement organs (Budiarto et al., 2018; Caraka et al., 2021). Hypertension is often occurred in both developed and developing countries, the symptoms are not felt and according to CDC, hypertension is characterized by an increase in systolic blood pressure exceeding $140 \mathrm{mmHg}$ and diastolic pressure exceeding $90 \mathrm{mmHg}$. Instantaneous lifestyle of people worldwide causes hypertension to remain at a high rate (Centers for Disease Control and Prevention (CDC), 2012).

The renin-angiotensin-aldosterone system is a major determinant in maintaining arterial blood pressure, one of which targets a component of angiotensinconverting enzyme (ACE), known as dipeptidyl-carboxypeptidase glycolyzed zinc. ACE acts as regulator of arterial blood pressure and electrolyte balance through the renin-angiotensin-aldosterone system (Mendoza Torres et al., 2015). Reninangiotensin-aldosterone system plays an important role in controlling arterial pressure including sodium balance (Schweda, 2015). Hypertension occurs due to the expression of angiotensin converting enzyme (ACE) affected by the environment. This expression correlates with blood pressure (Munro et al., 2017) and an occurrence of imbalance disruption between enzymes might cause hypertension.

A partial hydrolysis product of collagen called gelatin has an antihypertensive agent. It is known that gelatin originated from animal protein and contains bioactive peptides which function as an antihypertensive agent, in the form of ACE inhibitors (Aluko, 2015; Mills et al., 2016; Rosendorff et al., 2015). ACE inhibitors work by inhibiting the performance of an enzyme to produce angiotensin II that affects the narrowing of blood vessels (Annweiler et al., 2020). Bovine bone is determined to have collagen and its amino acid structure functioned as a bioactive peptide and ACE inhibitor working as an antihypertensive agent (Banerjee \& Shanthi, 2012).

Hypertension therapy using synthetic drugs has a series of negative effects, such as coughing, headache, nausea, vomiting, diarrhea or constipation, nervousness, skin rash, fatigue, and sudden weight loss (Kingman et al., 2017). Administration of antihypertensive drugs using bovine bone gelatin might be a potential option in the future. This implementation is carried out to provide knowledge of other usage regarding bovine bone gelatin as an antihypertensive agent. Furthermore, this implementation is also conducted to find out how much potential antihypertensive can occur as well as a basis for further research on a laboratory scale.

\section{General Characteristics of Hypertension Disease}

Hypertension is a major risk factor of cardiovascular disease which is known to be the number one cause of death in Indonesia (Tasmini et al., 2018) and an estimated 6\% of deaths in the world have a correlation with hypertension (Zhang et al., 2020). Hypertension is a state of systolic blood pressure $>120 \mathrm{mmHg}$ and $>80 \mathrm{mmHg}$. This disease is grouped into 3 stages, such as

How to cite:

Khikmawati, I., Rahayu, S. M., Amieni, A. N., \& Cahyadi, M. (2021). The Potency of Bovine Bone Gelatin as Antihypertensive Agent: A Review. Jurnal Ilmu dan Teknologi Hasil Ternak (JITEK), 16 (3), 153-165 
stage 1 130-139 / 80-89 $\mathrm{mmHg}$, stage 2 140-159 / 90-99 $\mathrm{mmHg}$ and stage $3 \geq 160 / \geq 100 \mathrm{mmHg}$ (Chen \& Chauhan, 2019). Lifestyle and behavior can affect blood pressure levels in the form of alcohol consumption, smoking and cases of metabolic syndrome by visceral obesity, insulin resistance, oxidative stress, endothelial dysfunction, activated reninangiotensin system, increased inflammatory mediators, and obstructive sleep apnea (Lackland \& Voeks, 2014). Excess consumption of salt and fatty foods can also be a factor in causing hypertension (Imelda et al., 2020).

The long-term impact of a hypertensive patient is the emergence of other diseases such as chronic kidney disease and as much as $28.4 \%$ of patients with chronic kidney disease in the United States from 1980 to 2010 suffered from hypertension (Xie et al., 2019). Untreated metabolic syndrome is at risk of having cardiovascular disease such as coronary heart disease and stroke (Tasmini et al., 2018).

\section{The Mechanism of Hypertension Treatment}

Hypertension treatment is given to patients based on the level of blood pressure. A successful hypertension treatment according to JNC 8 (The Eight Joint National Committee) is a blood pressure of $150 / 90 \mathrm{mmHg}$ in patients with the age of over 60 years and 140/80 $\mathrm{mmHg}$ in patients under 60 years. Treatment of hypertension can be done by administering antihypertensive, one of which is Angiotensin Converting Enzyme (ACE) inhibitors (James et al., 2014). The mechanism of hypertension treatment using ACE inhibitor is shown by Figure 1 (Turner \& Kodali, 2020).

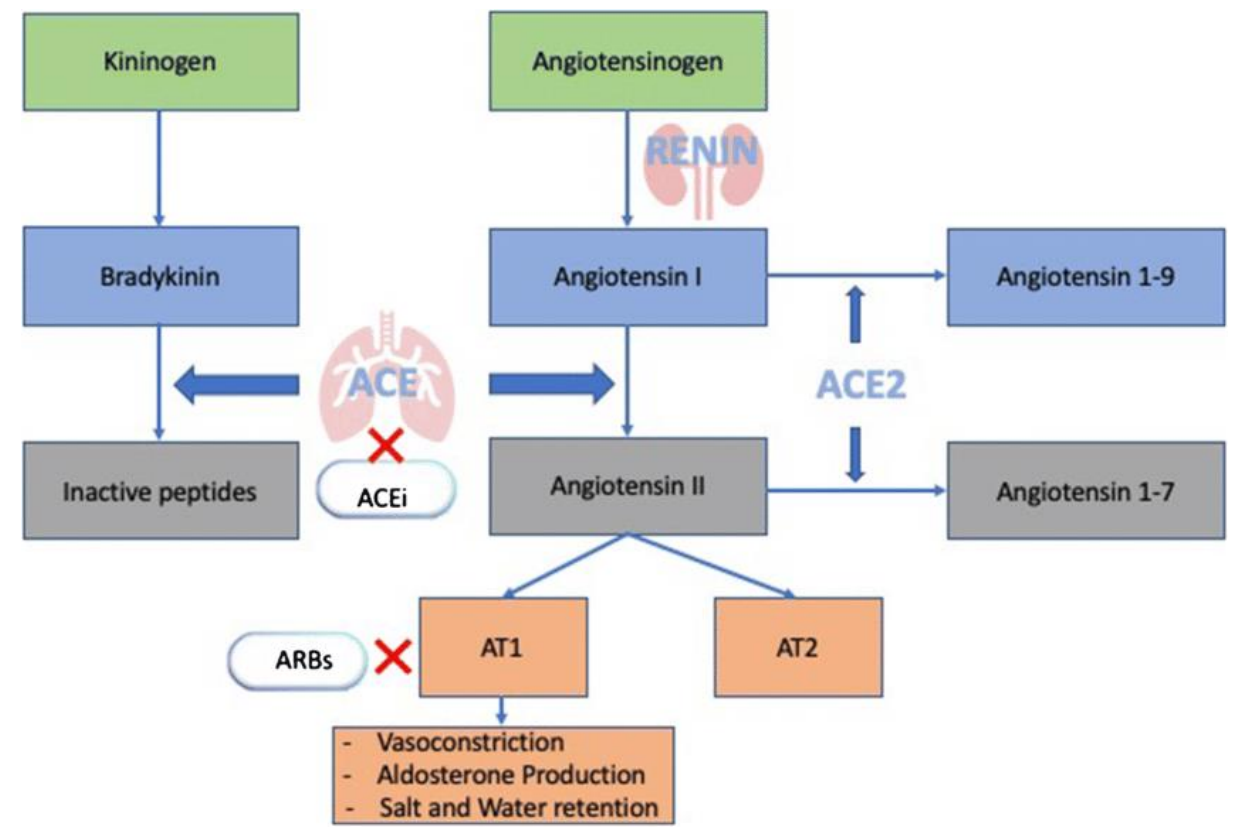

Source: Turner \& Kodali (2020).

Figure 1. Mechanism of ACE inhibitor (ACEi) and angiotensin receptor blocker (ARB). ACE is angiotensin-converting enzyme; ACE2 is angiotensin-converting enzyme 2; AT1 is angiotensin II receptor type 1; AT2 is angiotensin II receptor type 2.

The angiotensin converting enzyme I (ACE) is a key of enzyme for regulating blood pressure in vivo (Miralles et al., 2018). ACE activates the renin-angiotensinaldosterone pathway, promoting the conversion of angiotensin I to angiotensin II. ACE inhibitors are angiotensin-converting enzyme inhibitors that block the conversion of angiotensin I to angiotensin II. Angiotensin II is a powerful vasoconstrictor 
that, when inhibited, causes blood vessels to dilate and aldosterone output to decrease, lowering blood pressure (Chen et al., 2018; Knežević et al., 2017). ACE inhibitors work by inhibiting the peptidyl dipeptides converting enzyme that hydrolyzes angiotensin I to angiotensin II and activates bradykinin. ACE inhibitory was the $1^{\text {st }}$ medications applied to lower blood pressure in hypertension and can be found as synthetic ACE inhibitors drugs such as benazepril, captopril, enalapril, fosinopril, lisinopril, zestril, moexipril, perindopril, quinapril, accupril, ramipril, and trandolapril (Iwaniak et al., 2014). However, the ACE inhibitor drugs often cause effects such as angioedema, coughing, and hypotension (Miralles et al., 2018). Thus, alternative source for hypertension treatment and aimed for reducing blood pressure with less adverse effects have found on natural polypeptides from food proteins. Those findings said that the polypeptides having a similar structure with synthetic drugs and showing potential ACE inhibitory activities both in vivo and in vitro (Cao et al., 2019; FitzGerald et al., 2004).

\section{Collagen as Natural Inhibitor Peptides}

Collagen is a renewable natural resource that can be used as medical and chemical materials, food resources, and etc. (Pal \& Suresh, 2016). Bone, skin, and another part of animal husbandry contain a large number of collagens, exist in the connective tissue, and categorized as byproducts (Blanco et al., 2017). However, the usage of collagen is limited. This is caused by collagen's amino acid composition does not match with human needs and hard to be digested. Research and development for improving the use of collagen is done. Collagen is hydrolyzed to obtain the bioactive peptides in smaller sizes which have been found as peptides and amino acids compound (Chen et al., 2020). Some of collagen peptides, as bioactive peptides, were reported having a special function, such as ACE inhibitory activity, called cryptic peptides (Banerjee \& Shanthi, 2016).
Bioactive peptides are a specific part of food protein with low molecular weight, consisting of 2-30 amino acids released during the metabolic process (Ryder et al., 2016). Bioactive substances also beneficial to one's health and help to prevent diseases from developing. The major benefits of bioactive peptides are ACE inhibitor, antioxidant, antidiabetic, antiobesity, and antibacterial (Jakubczyk et al., 2020). The location of particular amino acid residues is crucial for robust antihypertensive action (Daliri et al., 2017). The in vitro treatment revealed that it can create ACE inhibitors when collagen from animal sources binds to a target on the active site (Aluko, 2015; Mills et al., 2016; Rosendorff et al., 2015). The ACE inhibitors sourced from protein are promising for safety. These confirmed ACE inhibitory peptides are containing 10-12 amino acids and having C-terminal hydrophobic side (Baehaki et al., 2016).

The C-terminal residue was found in hydrophobic side. Historically, the first source of ACE inhibitor found in snake venom, a mixture of peptides and enzymes that most of the inhibitory peptides contained the residues a $\mathrm{P}$ as the $\mathrm{C}$-terminal and $\mathrm{N}, \mathrm{I}$, and $\mathrm{P}$ near the $\mathrm{C}$-terminal. Then, it was theorized that, a bioactive peptide can act as ACE inhibitor having the region of hydrophobic C-terminal with $\mathrm{G}-\mathrm{X}^{\prime}-\mathrm{Y}^{\prime}$ amino acid arrangement $\left(\mathrm{X}^{\prime}\right.$ is often $\mathrm{P}, \mathrm{L}, \mathrm{I}$ or $\mathrm{A}$ and $\mathrm{Y}^{\prime}$ often $\mathrm{P}$ ) (Banerjee \& Shanthi, 2012). The structural activity of the ACE inhibitor by polypeptides is related to the presence of $\mathrm{C}$ - in tripeptide residues and hydrophobic amino acid residues (Leu, Ala, Val, Ile, Tyr, and Phe) (Escudero et al., 2012).

Inhibition occurs because the peptides on the ACE bind to the N-and/or C- ends of the ACE inhibitor, such as hydrophobic amino acids with aliphatic chains (Gly, Ile, Leu, and Val) at the $\mathrm{N}$-end and cyclic amino acids or aromatic chains (Pro, Tyr, and Trp) at the C-end of the ACE inhibitor (Fitzgerald \& Meisel, 2000; Vermeirssen et al., 2002). Various types of oligopeptides containing ACE inhibitors have been identified from 
collagen hydrolysate including Met-GlyPro, Gly-Pro-Leu, and Gly-Pro-Val (Campbell et al., 2014; Garfinkle, 2017), Ala-Hyp also has potential ACE inhibitors (Kim et al., 2001). The potential of ACE inhibitors is found in the Gly-X-Y repeating pattern (Herregods et al., 2011). Collagen hydrolyzes the X-Gly peptide from Pro-XGly-Pro chain and produces Gly-Pro at the $\mathrm{N}$ - end, Pro-X at the C- end (Ackerman et $a l .$, 1999). The high content of Gly and Pro can be potential precursors for bioactive peptides. Several enzymes are able to produce peptides with hydrophobic amino acid type at their $\mathrm{C}$ end thus considered as strong and potential candidates for $\mathrm{ACE}$ inhibitor activity (Aluko, 2015; GomezGuillen et al., 2011; Minkiewicz et al., 2011).

\section{The Profile of Bovine's Bone Gelatin}

Gelatin is a natural product obtained through partial hydrolysis of collagen from animal skin and bones with physicochemical properties that are water soluble, transparent, odorless, tasteless (GomezGuillen et al., 2011) and has reversible properties (sol to gel), expands in cold water, forms a film, affects the viscosity of the material and protects the colloid system (Wonganu, 2020). Gelatin is considered as a miracle food that can be applied in the pharmaceutical, medical, photography and food industries because it forms gel, viscosity and melts in the mouth (GomezGuillen et al., 2011). It can also be used as a stabilizer, gelling agent, and microencapsulation agent for food products such as jelly, milk, yogurt, ice cream, cheese and canned food (Koli et al., 2012), another important characteristic is high digestibility (Deviarny et al., 2015). Gelatin has bioactive properties in the form of antimicrobial (antioxidant) and antihypertensive properties by inhibiting angiotensin converting enzyme (ACE) (Gomez-Guillen et al., 2011).

Gelatin consists of amino acids such as glycine (Gly), proline (Pro) and 4-hydroxyproline (4Hyd). The general structure of gelatin is -Ala-Gly-Pro-ArgGly-Glu-4Hyd-Gly-Pro. The proline and hydroxyproline amino acids play an important role in the effect of the gel on gelatin (Syafiqoh, 2013). The complete content of essential and non-essential amino acids along with their percentage is shown in Table 1.

Table 1. Amino acid content in gelatin

\begin{tabular}{lccc}
\hline $\begin{array}{c}\text { Non-Essential Amino } \\
\text { Acid }\end{array}$ & Percentage $(\%)$ & $\begin{array}{c}\text { Essential } \\
\text { Amino Acid }\end{array}$ & Percentage (\%) \\
\hline Glycine & $26.00-27.00$ & Arginine & $8.60-9.30$ \\
Proline & $14.80-17.60$ & Lysine & $4.10-5.90$ \\
Hydroxyproline & $12.60-14.40$ & Leucine & $3.20-3.60$ \\
Glutamic acid & $10.20-11.70$ & Valine & $2.50-2.70$ \\
Alanine & $8.70-9.60$ & Phenylalanine & $2.20-2.26$ \\
Aspartic acid & $5.50-6.80$ & Threonine & $1.90-2.20$ \\
Serine & $3.20-3.60$ & Isoleucine & $1.40-1.70$ \\
Hydroxylysine & $0.76-1.50$ & Methionine & $0.60-1.00$ \\
Tyrosine & $0.49-1.10$ & Histidine & $0.60-1.00$ \\
Cysteine & $0.10-0.20$ & Tryptophan & $0.00-0.30$ \\
\hline
\end{tabular}

Source: Nur (2011).

Gelatin produced from bovine bones is classified as type B by demineralized bone. Type B gelatin using an alkaline solution has an isoelectric point at a $\mathrm{pH}$ of 4.7-5.4 (GMIA, 2012). The structure of bone collagen is different, shown in Figure 2 (Cao et al., 2020). The bone of the bovine femur has a compact shape, is a high source of collagen and is obtained from a slaughterhouse which has little 
contamination, making it suitable as a raw material for making gelatin (as gelling, thickening or stabilizing agent) (Laksana, 2016; Munda, 2013). The collagen molecules in bone bind to the nanoparticles of mineral $\mathrm{Ca}_{3}\left(\mathrm{PO}_{4}\right)_{2}$ or mineral phase closely and form a complex interlocking network. Its hierarchical structure is stabilized by molecular coil, interactions of intermolecular, and mechanical interlocking between hydroxyapatite crystals and spesific amino acid group (sequence of polyaspartic acid, residues of $\gamma^{-}$ carboxyglutamic acid, and sequences of glutamic acid) (Liu et al., 2016; Stock, 2015).

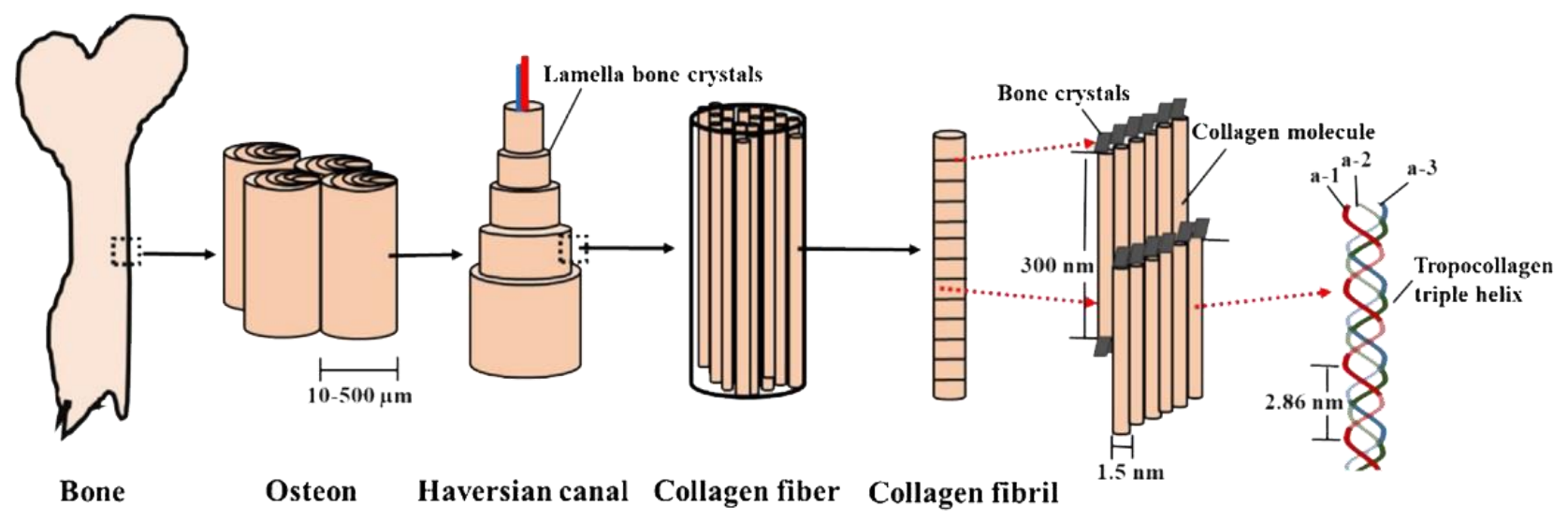

Source: Cao et al. (2020)

Figure 2. Hierarchial structure of bone form macro- to nano- scale

The physicochemical composition of beef bones is $33.3 \%$ gelatin, $3.85 \% \mathrm{CaCO}_{3}$, $57.35 \% \quad \mathrm{~K}_{3} \mathrm{PO}_{4}, 2.05 \% \quad \mathrm{Mg}_{3}\left(\mathrm{PO}_{4}\right)_{2}, 3,45 \%$ $\mathrm{Na}_{2} \mathrm{CO}_{3}$, specific gravity of $1.9 \mathrm{~g} / \mathrm{cm}^{3}$ (Septriansyah, 2000). Collagen is an amino acid protein that is dominated by the polypeptides $28,8 \%$ glycine, $15,5 \%$ proline, and $14,2 \%$ alanine which are the main ingredients for making gelatin (Chi et al., 2014; GMIA, 2012). The main raw material for gelatin is a collagen compound with the following breakdown reactions:
$\mathrm{C}_{102} \mathrm{H}_{149} \mathrm{~N}_{31} \mathrm{O}_{38}+\mathrm{H}_{2} \mathrm{O}$
$\rightarrow \quad \mathrm{C}_{102} \mathrm{H}_{151} \mathrm{~N}_{31} \mathrm{O}_{39}$
Collagen
Water
Gelatin

The reaction occurs at a temperature of 60$95^{\circ} \mathrm{C}$. An increase of temperature more than $95^{\circ} \mathrm{C}$ causes the breakdown of gelatin with the following reaction:

\section{$\mathrm{C}_{102} \mathrm{H}_{151} \mathrm{~N}_{31} \mathrm{O}_{39}+\mathrm{H}_{2} \mathrm{O} \rightarrow \mathrm{C}_{55} \mathrm{H}_{83} \mathrm{~N}_{17} \mathrm{O}_{18}+\mathrm{C}_{47} \mathrm{H}_{70} \mathrm{~N}_{14} \mathrm{O}_{18}$ Gelatin Water Semiglutin Hemicollin}

The collagen molecule is composed of approximately 20 amino acids in which there is a repeating polypeptide subunit (tropocollagen) containing 1050 amino acid residues in the individual collagen peptide chain (Ichsan, 2012). Collagen consists of three polypeptides twisted together to form a triple helix. The three tendrils of the polypeptide chain are tightly coiled around each other (Chi et al., 2014). One tropocollagen unit consists of three polypeptide chains. The pyrrolidine, proline, and hydroxyproline rings take part in forming the polypeptide chain and strengthening the triple helix. Tropocollagen will be denatured by heating or treatment with substances such as acids, bases, urea, and potassium permanganate. Collagen fibers might experience shrinkage if it was heated above the shrinkage temperature $\left(\mathrm{Ts}=45^{\circ} \mathrm{C}\right.$ ) and the split triple helix will have a longer size. The breakdown of these 
structures into random and water-soluble bonds produces gelatin (Hosseni et al., 2014).

Collagen is the main material of extracellular matrix for connective tissues (O'Keeffe et al., 2017). Collagen peptides, the subunit of collagen, will take part of formation for collagens and figure the connective tissues. Additionally, collagen peptides have the smaller size and easily can be digested into smaller molecules easily than collagen. What's more, collagen dipeptides and tri-peptides can be absorbed directly (Freeman, 2015) and in human body, collagen tri-peptides are absorbed more efficiently (Yamamoto et al., 2016). Two peptides from bovine collagen are confirmed having antihypertensive activity by in vivo testing (Yu et al., 2016).

\section{The Effectiveness Test of Bovine's Bone Gelatin Peptides}

Antihypertensive activity testing was carried out in vivo and in vitro. The potential bioconversion of ACE inhibitor peptides will react to oral administration, because the maximum absorption process depends on the target organ (Herregods et al., 2011; Noviani \& Vitrinurilawaty, 2017; Sarbon et al., 2019). In vivo experiments are typically performed on spontaneously hypertensive rats (SHR). The treatment was administered orally, and blood pressure was measured by the tail-cuff method and blood pressure monitoring (Fitzgerald \& Meisel, 2000; Herregods et al., 2011), shown in Figure 3 (Wang et al., 2017).

Treatment trials on rats were also conducted by giving a high salt diet using the post-test only control group design method. Male and female Wistar rats were treated with a high-salt diet of $3 \mathrm{ml} 8 \% \mathrm{NaCl}$ solution for 4 wk (Lailani et al., 2013). The measurement of blood pressure is done by intraperitoneal anesthetizing using $60 \mathrm{mg}$ of pentobarbital-Na. The rats' hair on the anterior neck was shaved and then operated to attach the trachea with a cannula. The carotid arteries are cannulated with a cannula on the transducer connected to a computer for blood pressure monitoring (Armenia et al., 2004).

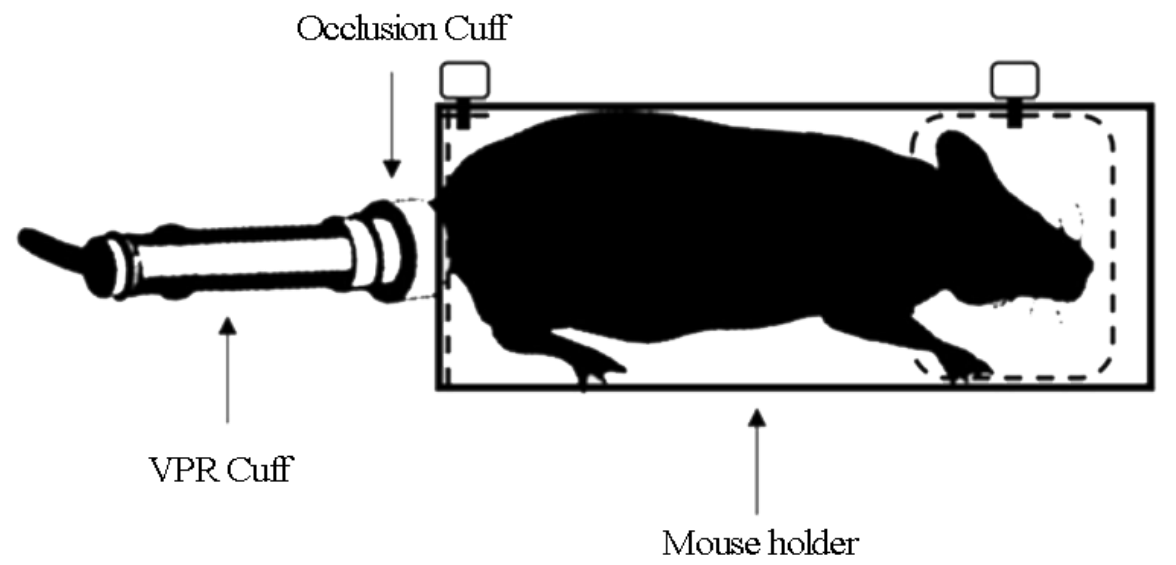

Source: Wang et al. (2017)

Figure 3. Schematic illustration of tail-cuff treatment on SHR

The in vivo antihypertensive test of bovine gelatin had been carried out using various types of peptides. It has also been known that short peptides derived from gelatin hydrolysate (e.g. Pro-Hyp) can get through the intestinal barrier and enter the blood stream by human (Iwai et al., 2005) or mice (Taga et al., 2016). The ACE inhibitor
Leu-Arg-Pro test in SHR injected intravenously with $30 \mathrm{mg} / \mathrm{kg}$ bovine hide gelatin peptide can reduce blood pressure in SHR by 15 mmHg (Kim et al., 2001). Tailcuff test was carried out for $12 \mathrm{~h}$ on SHR with $10 \mathrm{mg} / \mathrm{kg}$ and $30 \mathrm{mg} / \mathrm{kg}$ of RGL and RGM bovine bone gelatin hydrolysate. Through this test, maximum systolic blood 
pressure reduction was obtained by RGL-(Hyp)-GL and RGM-(Hyp)-GF at $30 \mathrm{mg} / \mathrm{kg}$ of $31.3 \mathrm{mmHg}$ and $38.6 \mathrm{mmHg}$ respectively (Cao et al., 2020). Other experiments on $30-50 \mathrm{kDa}$ (permeate $\mathrm{P} 1$ ) of bovine and pork collagen and 1-2 $\mathrm{kDa}$ (permeate P3) of hydrolyzed pig collagen, reduced blood pressure by $22 \mathrm{mmHg}$ and $21.33 \mathrm{mmHg}$ (Faria et al., 2008). Herregods et al. (2011), done the research for reducing blood pressure by tail-cuff method in SHR for $6 \mathrm{~h}$ using bovine hide, found that giving the single dose of $300 \mathrm{mg} / \mathrm{kg}$ could reduce systolic blood pressure at $17 \mathrm{mmHg}$. Thus, the antihypertensive effects reported in some studies conclude that the natural animal collagen, especially bovine bone collagen, has bioactive peptides for blood pressure-lowering properties.

Antihypertensive findings on bovine bone collagen are still limited. There are many forms of peptide protein in bovine bone collagen that have not been studied.

\section{CONCLUSION}

Bovine bone contains natural-source collagen peptides that are highly digested and safe for consumption. Several studies have been conducted to prove that collagen peptides have other functions as antihypertensive agents for lowering blood pressure with less adverse effects. Bovine collagen contained unique peptides which are structurally similar to those contained in synthetic drugs. It also performs antihypertensive activity and acts as ACE inhibitor in lowering blood pressure. It is supported with the large amount of Gly (27\%), Pro (17.6\%), and Hyp (14.4\%), and has a hydrophobic $\mathrm{C}$-terminal region with an amino acid sequence of G-X'- $\mathrm{Y}^{\prime}$ or Gly-X$Y$, which potent for ACE inhibitor. These results indicate that bioactive peptides of bovine bone collagen have the same potential as ACE inhibitor agents. The use of bovine bone gelatin is needed to be studied further to determine other ACE inhibitory peptides as antihypertensive agents.

\section{ACKNOWLEDGMENT}

This work was fully supported by Program Kreativitas Mahasiswa (PKM) with decree number: 1686/E2/TU/2020, Ministry of Education and Culture, Indonesia.

\section{REFERENCES}

Ackerman, M. S., Bhate, M., Shenoy, N., Beck, K., Ramshaw, J. A. M., \& Brodsky, B. (1999). Sequence dependence of the folding of collagenlike peptides. Journal of Biological Chemistry, 274(12), 7668-7673. https ://doi.org/10.1074/jbc.274.12.7668

Aluko, R. E. (2015). Antihypertensive peptides from food proteins. Annual Review of Food Science and Technology, 6(1), 235-262. https:// doi.org/10.1146/annurev-food-02281 4-015520

Annweiler, C., Cao, Z., Wu, Y., Faucon, E., Mouhat, S., Kovacic, H., \& Sabatier, J.-M. (2020). Counter-regulatory 'renin-angiotensin' system-based candidate drugs to treat COVID-19 diseases in SARS-CoV-2-infected patients. Infectious Disorders - Drug Targets, 20(4), 407-408. https://doi. org/10.2174/18715265206662005180 73329

Armenia, A., Munavvar, A. S., Abdullah, N. A., Helmi, A., \& Johns, E. J. (2004). The contribution of adrenoceptor subtype(s) in the renal vasculature of diabetic spontaneously hypertensive rats. British Journal of Pharmacology, 142(4), 719-726. https://doi.org/10.10 38/sj.bjp.0705842

Baehaki, A., Suhartono, M. T., Sukarno, Syah, D., \& Setyahadi, S. (2016). Collagen peptides from fish skin with Angiotensin I-Converting Enzyme (ACE) inhibitor and cancer antiproliferative activity. Research Journal of Pharmaceutical, Biological and Chemical Sciences, 7(1), 19942000. 
Banerjee, P., \& Shanthi, C. (2012). Isolation of novel bioactive regions from bovine Achilles tendon collagen having angiotensin I-converting enzyme-inhibitory properties. Process Biochemistry, 47(12), 2335-2346. https://doi.org/10.1016/j.procbio.201 2.09.012

Banerjee, P., \& Shanthi, C. (2016). Cryptic peptides from collagen: a critical review. Protein \& Peptide Letters, 23(7), 664-672. https://doi.org/10.21 74/0929866522666160512151313

Blanco, M., Vázquez, J., Pérez-Martín, R., \& Sotelo, C. (2017). Hydrolysates of fish skin collagen: an opportunity for valorizing fish industry byproducts. Marine Drugs, 15(5), 131. https://doi.org/10.3390/md15050131

Budiarto, A., Febriana, T., Suparyanto, T., Caraka, R. E., \& Pardamean, B. (2018). Health assistant wearablebased data science system model: a pilot study. 2018 International Conference on Information Management and Technology (ICIMTech), 438-442. https://doi.org/ 10.1109/ICIMTech.2018.8528102

Campbell, N. R. C., Lackland, D. T., \& Niebylski, M. L. (2014). High blood pressure: why prevention and control are urgent and important-a 2014 fact sheet from the world hypertension league and the international society of hypertension. The Journal of Clinical Hypertension, 16(8), 551-553. https://doi.org/10.1111/jch.12372

Cao, S., Wang, Y., Hao, Y., Zhang, W., \& Zhou, G. (2020). Antihypertensive effects in vitro and in vivo of novel angiotensin-converting enzyme inhibitory peptides from bovine bone gelatin hydrolysate. Journal of Agricultural and Food Chemistry, 68(3), 759-768. https://doi.org/10.10 21/acs.jafc.9b05618

Cao, S., Wang, Y., Xing, L., Zhang, W., \& Zhou, G. (2020). Structure and physical properties of gelatin from bovine bone collagen influenced by acid pretreatment and pepsin. Food and Bioproducts Processing, 121, 213-223. https://doi.org/10.1016/j.fbp .2020.03.001

Caraka, R. E., Noh, M., Chen, R.-C., Lee, Y., Gio, P. U., \& Pardamean, B. (2021). Connecting climate and communicable disease to penta helix using hierarchical likelihood structural equation modelling. Symmetry, $\quad 13(4), \quad 657$. https://doi.org/10.3390/sym13040657

Centers for Disease Control and Prevention (CDC). (2012). Vital Signs: Awareness and Treatment Of Uncontrolled Hypertension Among Adults--United States, 2003-2010. MMWR. Morbidity and Mortality Weekly Report, 61(35), 703-709.

Chen, H.-Y., \& Chauhan, S. P. (2019). Hypertension among women of reproductive age: impact of 2017 american college of cardiology/american heart association high blood pressure guideline. International Journal of Cardiology Hypertension, 1, 100007. https://doi. org/10.1016/j.ijchy.2019.100007

Chen, M., Li, Y., \& Huang, G. (2020). Potential health functions of collagen bioactive peptides: a review. American Journal of Biochemistry and Biotechnology, 16(4), 507-519. https://doi.org/10.3844/ajbbsp.2020.5 07.519

Chen, Y. J., Li, L. J., Tang, W. L., Song, J. Y., Qiu, R., Li, Q., Xue, H., \& Wright, J. M. (2018). First-line drugs inhibiting the renin angiotensin system versus other first-line antihypertensive drug classes for hypertension. Cochrane Database of Systematic Reviews, 2018(11). https://doi.org/10.1002/14651858.CD 008170.pub3

Daliri, E., Oh, D., \& Lee, B. (2017). Bioactive peptides. Foods, 6(5), 1-21. https://doi.org/10.3390/foods6050032

Deviarny, C., Friardi, F., \& Rissa, M. M. (2015). Pengaruh konsentrasi gelatin 
dalam formulasi permen jeli penghilang bau mulut dari minyak atsiri buah kapulaga (Amomumcompactumsol. Ex Maton). Scientia: Jurnal Farmasi Dan Kesehatan, 5(2), 103. https://doi.org/ 10.36434/scientia.v5i2.30

Escudero, E., Aristoy, M.-C., Nishimura, H., Arihara, K., \& Toldrá, F. (2012). Antihypertensive effect and antioxidant activity of peptide fractions extracted from Spanish drycured ham. Meat Science, 91(3), 306311. https://doi.org/10.1016/j.meatsci. 2012.02.008

Faria, M., da Costa, E. L., Gontijo, J. A. R., $\&$ Netto, F. M. (2008). Evaluation of the hypotensive potential of bovine and porcine collagen hydrolysates. Journal of Medicinal Food, 11(3), 560-567. https://doi.org/10.1089/jmf. 2007.0573

FitzGerald, R. J., \& Meisel, H. (2000). Milk protein-derived peptide inhibitors of angiotensin-I-converting enzyme. British Journal of Nutrition, 84(S1), 33-37. https://doi.org/10.1017/S000 7114500002221

FitzGerald, R. J., Murray, B. A., \& Walsh, D. J. (2004). Hypotensive peptides from milk proteins. The Journal of Nutrition, 134(4), 980S-988S. https://doi.org/10.1093/jn/134.4.980S

Freeman, H. J. (2015). Clinical relevance of intestinal peptide uptake. World Journal of Gastrointestinal Pharmacology and Therapeutics, 6(2), 22. https://doi.org/10.4292/wjg pt.v6.i2.22

Fu, Y., Young, J. F., Rasmussen, M. K., Dalsgaard, T. K., Lametsch, R., Aluko, R. E., \& Therkildsen, M. (2016). Angiotensin I-converting enzyme-inhibitory peptides from bovine collagen: insights into inhibitory mechanism and transepithelial transport. Food Research International, 89, 373-381. https://doi.org/10.1016/j.foodres.2016 .08 .037
Garfinkle, M. A. (2017). Salt and essential hypertension: pathophysiology and implications for treatment. Journal of the American Society of Hypertension, 11(6), 385-391. https://doi.org/10.10 16/j.jash.2017.04.006

Gelatin Manufacturers Institute of America. (2012). Gelatin Handbook GMIA. In Gelatin handbook. Atlantic Gelatin / Kraft Foods Global Inc.

Goldhaber, P. (1964). Collagen and bone. The Journal of the American Dental Association, 68(6), 825-832. https:// doi.org/10.14219/jada.archive.1964.0 208

Gómez-Guillén, M. C., Giménez, B., LópezCaballero, M. E., \& Montero, M. P. (2011). Functional and bioactive properties of collagen and gelatin from alternative sources: A review. Food Hydrocolloids, 25(8), 18131827. https://doi.org/10.1016/j.food hyd.2011.02.007

Herregods, G., Van Camp, J., Morel, N., Ghesquière, B., Gevaert, K., Vercruysse, L., Dierckx, S., Quanten, E., \& Smagghe, G. (2011). Angiotensin i-converting enzyme inhibitory activity of gelatin hydrolysates and identification of bioactive peptides. Journal of Agricultural and Food Chemistry, 59(2), 552-558. https://doi.org/10.10 21/jf1037823

Ichsan, M. Z. (2012). Sintesis Makroporus Komposit Kolagen-Hidroksiapatit Sebagai Kandidat Bone Graft. Universitas Airlangga.

Imelda, I., Sjaaf, F., \& Puspita, T. (2020). Faktor-faktor yang berhubungan dengan kejadian hipertensi pada lansia di puskesmas air dingin lubuk minturun. Health \& Medical Journal, 2(2), 68-77. https://doi.org/10.33854/ heme.v2i 2.532

Iwai, K., Hasegawa, T., Taguchi, Y., Morimatsu, F., Sato, K., Nakamura, Y., Higashi, A., Kido, Y., Nakabo, Y., \& Ohtsuki, K. (2005). Identification of food-derived collagen peptides in 
human blood after oral ingestion of gelatin hydrolysates. Journal of Agricultural and Food Chemistry, 53(16), 6531-6536. https://doi.org/10. 1021/jf050206p

Iwaniak, A., Minkiewicz, P., \& Darewicz, M. (2014). Food-originating ACE inhibitors, including antihypertensive peptides, as preventive food components in blood pressure reduction. Comprehensive Reviews in Food Science and Food Safety, 13(2), 114-134. https://doi.org/10.1111/154 $1-4337.12051$

Jakubczyk, A., Karaś, M., RybczyńskaTkaczyk, K., Zielińska, E., \& Zieliński, D. (2020). Current trends of bioactive peptides-new sources and therapeutic effect. Foods, 9(7), 846. https://doi.org/10.3390/foods9070846

James, P. A., Oparil, S., Carter, B. L., Cushman, W. C., DennisonHimmelfarb, C., Handler, J., Lackland, D. T., LeFevre, M. L., MacKenzie, T. D., Ogedegbe, O., Smith, S. C., Svetkey, L. P., Taler, S. J., Townsend, R. R., Wright, J. T., Narva, A. S., \& Ortiz, E. (2014). 2014 Evidence-based guideline for the management of high blood pressure in adults. JAMA, 311(5), 507-520. https://doi.org/10.1001/jama.2013.28 4427

Kim, S.-K., Byun, H.-G., Park, P.-J., \& Shahidi, F. (2001). Angiotensin i converting enzyme inhibitory peptides purified from bovine skin gelatin hydrolysate. Journal of Agricultural and Food Chemistry, 49(6), 2992-2997. https://doi.org/10.1021/jf001119u

Kingman, M., Archer-Chicko, C., Bartlett, M., Beckmann, J., Hohsfield, R., \& Lombardi, S. (2017). Management of prostacyclin side effects in adult patients with pulmonary arterial hypertension. Pulmonary Circulation, 7(3), 598-608. https://doi.org/10.1177 /2045893217719250

Knežević, T., Gellineo, L., Jelaković, A., Premužić, V., Dika, Ž., Laganović,
M., \& Jelaković, B. (2019). Treatment of Hypertension induced albuminuria. Current Pharmaceutical Design, 24(37), 4404-4412. https://doi.org/10. 2174/1381612825666181126170354

Koli, J. M., Basu, S., Nayak, B. B., Patange, S. B., Pagarkar, A. U., \& Gudipati, V. (2012). Functional characteristics of gelatin extracted from skin and bone of Tiger-toothed croaker (Otolithes ruber) and Pink perch (Nemipterus japonicus). Food and Bioproducts Processing, 90(3), 555-562. https:// doi.org/10.1016/j.fbp.2011.08.001

Lackland, D. T., \& Voeks, J. H. (2014). Metabolic syndrome and hypertension: regular exercise as part of lifestyle management. Current Hypertension Reports, 16(11), 1-7. https://doi.org/10.1007/s11906-0140492-2

Lailani, M., Edward, Z., \& Herman, R. B. (2013). Gambaran tekanan darah tikus wistar jantan dan betina setelah pemberian diet tinggi garam. Jurnal Kesehatan Andalas, 2(3), 146-150. https://doi.org/10.25077/jka.v2i3.154

Laksana, O. D. (2016). Pengaruh Penambahan Minyak Atsiri Temulawak (curcuma xanthorrhiza roxb.) dan Plasticizer Gliserol Pada Edible Film Berbasis Gelatin Komersial Terhadap Sifat Fisik Mekanik Serta Aktivitas Antioksidan. Universitas Sebelas Maret.

Liu, Y., Luo, D., \& Wang, T. (2016). Hierarchical structures of bone and bioinspired bone tissue engineering. Small, 12(34), 4611-4632. https://doi. org/10.1002/smll.201600626

Mendoza-Torres, E., Oyarzún, A., Mondaca-Ruff, D., Azocar, A., Castro, P. F., Jalil, J. E., Chiong, M., Lavandero, S., \& Ocaranza, M. P. (2015). ACE2 and vasoactive peptides: novel players in cardiovascular/renal remodeling and hypertension. Therapeutic Advances in Cardiovascular Disease, 9(4), 217237. https://doi.org/10.1177/1753944 
715597623

Mills, K. T., Bundy, J. D., Kelly, T. N., Reed, J. E., Kearney, P. M., Reynolds, K., Chen, J., \& He, J. (2016). Global disparities of hypertension prevalence and control. Circulation, 134(6), 441450. https://doi.org/10.1161/CIRCU LATIONAHA.115.018912

Minkiewicz, P., Dziuba, J., \& Michalska, J. (2011). Bovine meat proteins as potential precursors of biologically active peptides - a computational study based on the BIOPEP database. Food Science and Technology International, 17(1), 39-45. https:// doi.org/10.1177/1082013210368461

Miralles, B., Amigo, L., \& Recio, I. (2018). Critical review and perspectives on food-derived antihypertensive peptides. Journal of Agricultural and Food Chemistry, 66(36), 9384-9390. https:// doi.org/10.1021/acs.jafc.8b02603

Munda, M. (2013). Pengaruh Konsentrasi Asam Asetat Dan Lama Demineralisasi Terhadap Kuantitas dan Kualitas Gelatin Tulang Ayam. Universitas Hasanuddin.

Noviani, N., \& Vitrinurilawaty. (2017). Farmakologi. Kementrian Kesehatan Republik Indonesia.

Nur, S. (2011). Dukungan Rekayasa Sistem Kelembagaan Jaminan Mutu Pasokan Bahan Baku Kulit Sapi Untuk Pengembangan Agroindustri Gelatin. IPB University.

O’Keeffe, M. B., Norris, R., Alashi, M. A., Aluko, R. E., \& FitzGerald, R. J. (2017). Peptide identification in a porcine gelatin prolyl endoproteinase hydrolysate with angiotensin converting enzyme (ACE) inhibitory and hypotensive activity. Journal of Functional Foods, 34, 77-88. https:// doi.org/10.1016/j.jff.2017.04.018

Pal, G. K., \& Suresh, P. V. (2016). Sustainable valorisation of seafood by-products: Recovery of collagen and development of collagen-based novel functional food ingredients. Innovative Food Science \& Emerging
Technologies, 37, 201-215. https:// doi.org/10.1016/j.ifset.2016.03.015

Parchami Nejad, F., Tafvizi, F., Tajabadi Ebrahimi, M., \& Hosseni, S. E. (2014). Optimization of multiplex PCR for the identification of animal species using mitochondrial genes in sausages. European Food Research and Technology, 239(3), 533-541. https://doi.org/10.1007/s00217-0142249-1

Rosendorff, C., Lackland, D. T., Allison, M., Aronow, W. S., Black, H. R., Blumenthal, R. S., Cannon, C. P., de Lemos, J. A., Elliott, W. J., Findeiss, L., Gersh, B. J., Gore, J. M., Levy, D., Long, J. B., O’Connor, C. M., O’Gara, P. T., Ogedegbe, G., Oparil, S., \& White, W. B. (2015). Treatment of hypertension in patients with coronary artery disease. Circulation, 131(19), e435-e470. https://doi.org/10.1161/ CIR.0000000000000207

Ryder, K., Bekhit, A. E.-D., McConnell, M., \& Carne, A. (2016). Towards generation of bioactive peptides from meat industry waste proteins: Generation of peptides using commercial microbial proteases. Food Chemistry, 208, 42-50. https://doi. org/10.1016/j.foodchem.2016.03.121

Sarbon, N. M., Howell, N. K., \& Wan Ahmad, W. A. N. (2019). Angiotensin-I converting enzyme (ACE) inhibitory peptides from chicken skin gelatin hydrolysate and its antihypertensive effect in spontaneously hypertensive rats. International Food Research Journal, 26(3), 903-911.

Schweda, F. (2015). Salt feedback on the renin-angiotensin-aldosterone system. Pflügers Archiv - European Journal of Physiology, 467(3), 565-576. https:// doi.org/10.1007/s00424-014-1668-y

Septriansyah, C. (2000). Kajian Proses Pembuatan Gelatin Dari Hasil Ikutan Tulang Ayam Dalam Kondisi Asam. Bogor Agricultural University.

Syafiqoh, F. (2013). Analisis Gelatin Sapi 
dan Gelatin Babi pada Produk Cangkang Kapsul Keras Obat dan Vitamin Menggunakan FTIR dan KCKT.

Taga, Y., Kusubata, M., Ogawa-Goto, K., \& Hattori, S. (2016). Efficient absorption of $\mathrm{x}$-hydroxyproline (Hyp)-Gly after oral administration of a novel gelatin hydrolysate prepared using ginger protease. Journal of Agricultural and Food Chemistry, 64(14), 2962-2970. https://doi.org/10. 1021/acs.jafc.6b00609

Tasmini, T., Farmawati, A., Sunarti, S., Hastuti, P., Sadewa, A. H., Prasetyastuti, P., \& Ngadikun, N. (2018). Kadar glukosa darah dan tekanan darah pada penduduk pedesaan dan perkotaan di Daerah Istimewa Yogyakarta. Journal of Community Empowerment for Health, 1(1), 45-53. https://doi.org/10.22146/ jcoemph.39569

Turner, J. M., \& Kodali, R. (2020). Should angiotensin-converting enzyme inhibitors ever be used for the management of hypertension? current cardiology reports, 22(9), 95. https:// doi.org/10.1007/s11886-020-01352-8

Vermeirssen, V., Van Camp, J., \& Verstraete, W. (2002). Optimisation and validation of an angiotensinconverting enzyme inhibition assay for the screening of bioactive peptides. Journal of Biochemical and Biophysical Methods, 51(1), 75-87. https://doi.org/10.1016/S0165-022X (02)00006-4
Wang, Y., Thatcher, S. E., \& Cassis, L. A. (2017). Measuring blood pressure using a noninvasive tail cuff method in mice. Methods in Molecular Biology, 1614, 69-73. https://doi.org/10.1007 1978-1-4939-7030-8_6

Wonganu, B. (2020). Application of gelatin derived from waste tilapia scales to an antibiotic hydrogel pad. E3S Web of Conferences, 141, 03004. https://doi. org/10.1051/e3sconf/202014103004

Xie, K., Bao, L., Jiang, X., Ye, Z., Bing, J., Dong, Y., Gao, D., Ji, X., Jiang, T., Li, J., Li, Y., Luo, S., Mao, W., Peng, D., Qu, P., Song, S., Wang, H., Wang, Z., $\mathrm{Xu}, \mathrm{B} ., \mathrm{Li}, \mathrm{Y}$. (2019). The association of metabolic syndrome components and chronic kidney disease in patients with hypertension. Lipids in Health and Disease, 18(1), 1-9. https:// doi.org/10.1186/s12944-019-1121-5

Yamamoto, S., Deguchi, K., Onuma, M., Numata, N., \& Sakai, Y. (2016). Absorption and urinary excretion of peptides after collagen tripeptide ingestion in humans. Biological \& Pharmaceutical Bulletin, 39(3), 428434. https://doi.org/10.1248/bpb.b1500624

Zhang, Y., Yang, H., Wang, R., Zhao, F., Liu, T., Zhang, Y., Guo, Z., \& Cong, H. (2020). An analysis of medication prescriptions for hypertension in urban and rural residents in tianjin. Advances in Therapy, 37(10), 44144426. https://doi.org/10.1007/s12325020-01475-y 